\title{
Mitochondrial DNA variation analysis suggests extreme low genetic diversity in Guizhou snub-nosed monkeys (Rhinopithecus brelichi)
}

\author{
PAN HuiJuan ${ }^{1}$, SHI FangLei ${ }^{1}$, CHANG ZongFei ${ }^{2,3}$, XIANG ZuoFu ${ }^{4}$, SUN TingTing ${ }^{5}$, \\ LIU ZhiJin ${ }^{2} \&$ LI Ming ${ }^{2}$ \\ ${ }^{1}$ College of Nature Conservation, Beijing Forestry University, Beijing 100083, China; \\ ${ }^{2}$ Key Laboratory of Animal Ecology and Conservation Biology, Institute of Zoology, Chinese Academy of Sciences, Beijing 100101, China; \\ ${ }^{3}$ Graduate University of Chinese Academy of Sciences, Beijing 100049, China; \\ ${ }^{4}$ College of Life Sciences, Central South University of Forestry and Technology, Changsha 410004, China; \\ ${ }^{5}$ College of Life Sciences, Center China Normal University, Wuhan 430079, China
}

Received Feburary 25, 2011; accepted April 15, 2011

Guizhou snub-nosed monkey (Rhinopithecus brelichi) is a unique, endangered primate in China, mainly distributed in Fanjing Mountain National Natural Reserve, Guizhou Province, in an area of $275 \mathrm{~km}^{2}$. Recently, habitat loss and fragmentation have caused population isolation. To assess genetic diversity within this species and its population structure, we sequenced $400 \mathrm{bp}$ of the hypervariable I segment from the mitochondrial DNA control region for 128 individuals. Only one haplotype was identified from these individuals. Compared with other primate species, $R$. brelichi can be regarded as a species with very low genetic diversity, which further adds to the conservation concern.

Rhinopithecus brelichi, mitochondrial DNA, genetic diversity, conservation

Citation: $\quad$ Pan H J, Shi F L, Chang Z F, et al. Mitochondrial DNA variation analysis suggests extreme low genetic diversity in Guizhou snub-nosed monkeys (Rhinopithecus brelichi). Chinese Sci Bull, 2011, 56: 2541-2544, doi: 10.1007/s11434-011-4522-2

The genus of snub-nosed monkeys (Rhinopithecus, of Colobinae, Cercopithecidae) comprises 4 species, 3 of which are endemic to China (the golden or Sichuan snub-nosed monkey, $R$. roxellana; the black or Yunnan snub-nosed monkey, R. bieti; and the gray or Guizhou snub-nosed monkey, $R$. brelichi). The 4th species is distributed in northern Vietnam (Tonkin's snub-nosed monkey, $R$. avunculus). Recently, a new species, $R$. strykeri, has been found in a small region of north eastern Myanmar [1]. Fossil records indicate that snub-nosed monkeys were widely distributed in China and neighboring countries during the Pleistocene [2,3]. However, the current habitats of the extant species are separated from each other and they are confined to very limited areas in isolated mountainous regions in Sichuan, Yunnan, Guizhou, Hubei, Shanxi, Gansu, Tibet,

*Corresponding author (email: lim@ioz.ac.cn) northern Vietnam and north eastern Myanmar [4]. Current census data suggests a very gloomy picture for all of these species, with 20000 individuals of $R$. roxellana but only $1500 R$. bieti, 750 R. brelichi, 260-330 R. strykeri, and $130-350 R$. avunculus in the wild [1,5-9].

$R$. brelichi is categorized as an endangered species by the World Conservation Union [10], and is also listed as a Category I species under Chinese Wild Animal Protection Law. At present, $R$. brelichi is restricted to approximately 750 individuals living in a small region in the Mt. Fanjing area of northwest Guizhou Province, China, over a range of $275 \mathrm{~km}^{2}$ in Fanjing Mountain National Nature Reserve [9]. Mt. Fanjing is a popular Chinese tourist destination and holiday location. It is located between $27^{\circ} 46^{\prime} 50^{\prime \prime} \mathrm{N}$ and $28^{\circ} 1^{\prime} 30^{\prime \prime} \mathrm{N}, 108^{\circ} 35^{\prime} 55^{\prime \prime} \mathrm{E}$ and $108^{\circ} 48^{\prime} 30^{\prime \prime} \mathrm{E}$. Despite being legally protected, $R$. brelichi is seriously threatened because of habitat loss. 
Research on the amount of genetic variation among $R$. brelichi individuals has been limited. Until now, there has been no large scale study of the population genetics of $R$. brelichi. For $R$. brelichi, a threatened species with a limited population size, sound knowledge of its evolutionary history and contemporary genetic structure is likely to help management for its conservation [11]. In the present study, we collected samples from 128 individuals throughout the current distribution of the species, and analyzed the genetic diversity and population structure using the mitochondrial DNA control region (CR).

\section{Materials and methods}

\subsection{Sample collection and DNA extraction}

We conducted the study at Yangaoping $\left(27^{\circ} 58^{\prime} \mathrm{N}, 108^{\circ} 45^{\prime} \mathrm{E}\right)$, which covers approximately $10-12 \mathrm{~km}^{2}$ of temperate forest in the Fanjing Mountain National Nature Reserve (Figure 1). The focal individuals form part of a fission-fusion group of approximately 450 individuals in spring, summer, and early autumn [10], and 4 identified groups varying from 50 to 200 individuals in late autumn and winter [12]. Fecal samples of different monkey families from 10 sleeping sites (Table 1 and Figure 1) were collected, during direct behavioral observations when the monkeys were in sleeping trees, and stored in $95 \%$ ethanol. To avoid resampling the same individual, each dropping was distinguished by freshness, size, shape, and color, and feces found less than $1.5 \mathrm{~m}$ apart were not sampled [13]. To prevent contamination during DNA extraction, benches and plasticware were cleaned with $10 \%$ bleach and sterile water and then exposed to UV light for $30 \mathrm{~min}$. We used 20 extraction controls and none produced positive amplification during subsequent polymerase chain reaction (PCR). Total genomic DNA from fecal samples was extracted with the DNA Stool Mini Kit from Qiagen.

\subsection{Amplification and sequencing}

Four-hundred base pairs (bp) of the CR hypervariable I

Table 1 Distribution of sampling locations of Rhinopithecus brelichi within the Yangaoping area of Fanjing Mountain National Nature Reserve, Guizhou Province, China

\begin{tabular}{cccc}
\hline Site & Location & Sample size & Altitude $(\mathrm{m})$ \\
\hline 1 & $27^{\circ} 58.686^{\prime} \mathrm{N} ; 108^{\circ} 45.197^{\prime} \mathrm{E}$ & 5 & 1900 \\
2 & $27^{\circ} 58.873^{\prime} \mathrm{N} ; 108^{\circ} 45.420^{\prime} \mathrm{E}$ & 7 & 1800 \\
3 & $27^{\circ} 58.863^{\prime} \mathrm{N} ; 108^{\circ} 45.395^{\prime} \mathrm{E}$ & 10 & 1780 \\
4 & $27^{\circ} 58.677^{\prime} \mathrm{N} ; 108^{\circ} 45.033^{\prime} \mathrm{E}$ & 19 & 1900 \\
5 & $27^{\circ} 59.218^{\prime} \mathrm{N} ; 108^{\circ} 45.259^{\prime} \mathrm{E}$ & 19 & 1820 \\
6 & $27^{\circ} 58.645^{\prime} \mathrm{N} ; 108^{\circ} 46.138^{\prime} \mathrm{E}$ & 7 & 1580 \\
7 & $27^{\circ} 58.637^{\prime} \mathrm{N} ; 108^{\circ} 45.122^{\prime} \mathrm{E}$ & 8 & 1950 \\
8 & $27^{\circ} 59.048^{\prime} \mathrm{N} ; 108^{\circ} 45.420^{\prime} \mathrm{E}$ & 24 & 1750 \\
9 & $27^{\circ} 58.305^{\prime} \mathrm{N} ; 108^{\circ} 45.465^{\prime} \mathrm{E}$ & 4 & 1920 \\
10 & $27^{\circ} 58.861^{\prime} \mathrm{N} ; 108^{\circ} 46.154^{\prime} \mathrm{E}$ & 25 & 1800 \\
Total & & 128 & \\
\hline
\end{tabular}

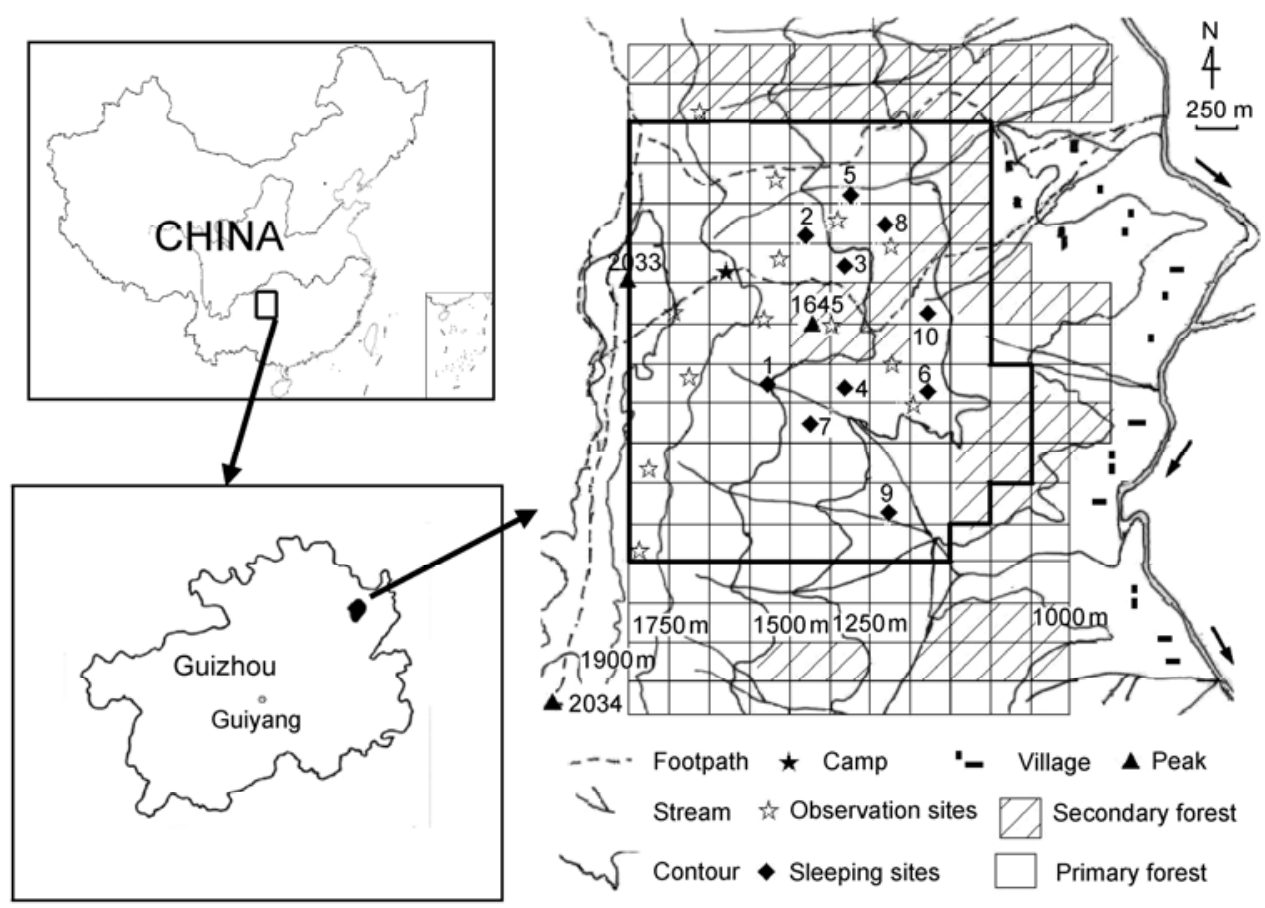

Figure 1 Map of the present distribution of sleeping sites of Rhinopithecus brelichi within the Yangaoping area of Fanjing Mountain National Nature Reserve, Guizhou, China. The sleeping sites indicate sampling locations of the present study. 
segment were amplified and sequenced. The primers were GH (5'-AACTGGCATTCTATTTAAACTAC-3') and GL (5'-ATTGATTTCACGGAGGATGGT-3') provided by Dr. Christian Roos (German Primate Center, Göttingen). Amplification was performed in a total volume of $50 \mu \mathrm{L}$ containing $50 \mathrm{mmol} / \mathrm{L} \mathrm{KCl}, 10 \mathrm{mmol} / \mathrm{L}$ Tris- $\mathrm{HCl}, 1.5 \mathrm{mmol} / \mathrm{L}$ $\mathrm{Mg}^{2+}, 200 \mu \mathrm{mol}$ of each dNTP, $0.2 \mu \mathrm{mol}$ of each primer, 1.5 U Hotstart Taq DNA polymerase (Qiagen), and $1 \mu \mathrm{g} / \mu \mathrm{L}$ BSA and approximately $\leqslant 10 \mathrm{ng}$ of genomic DNA. Forty cycles were used on a Perkin-Elmer Cetus 9700 DNA thermocycler with pre-denaturing at $95^{\circ} \mathrm{C}$ for $15 \mathrm{~min}$; denaturing at $95^{\circ} \mathrm{C}$ for $60 \mathrm{~s}$, annealing at $56^{\circ} \mathrm{C}$ for $60 \mathrm{~s}$, primer extension at $72^{\circ} \mathrm{C}$ for $60 \mathrm{~s}$; and a final $10 \mathrm{~min}$ of extension at $72^{\circ} \mathrm{C}$. Positive (blood-extracted DNA) and negative (water) controls were used to check PCR performance and contamination. The results of the PCR amplifications were checked by running an aliquot on a $1 \%$ agarose gel stained with ethidium bromide. Subsequently, PCR products were purified with Spin Column-PCR Purification Kit (Shanghai Huaxun Biology and Technology Ltd.) and sequenced with the Prism BigDyeTM Terminator Ready Reaction Kit (Applied Biosystem Inc.) and an ABI 377 or an ABI-PRISMTM 3100 Genetic Analyzer, according to manufacturer's manual. To avoid errors in amplification and sequencing, PCR amplification of entire samples was performed twice or more and the products were sequenced for both strands.

\subsection{Data analysis}

Forward and reverse sequencing was performed for each individual, and sequences were aligned using Clustal X [14] and rechecked by eye. Haplotypes were identified using Mega 2.1 [15]. Genetic diversity within populations was estimated as haplotype diversities $(h)$ and nucleotide diversities $(\pi)$ [16] using DnaSP 3.0 [17]. The pair-wise sequence difference among the haplotypes was calculated by the Kimura 2-parameter model using MEGA 2.1 [15].

\section{Results and discussion}

In the study, samples from 128 individuals belonging to 10 monkey families were collected (Table 1). Four-hundred bp $\mathrm{CR}$ sequences were amplified from the 128 samples. Of the total 400 nucleotide positions, there were no variable sites and only one haplotype was identified from all individuals (GenBank No. JF739863). The nucleotide composition of the 400 -bp CR region is $34.75 \%$ of A, $28 \%$ of T, $23.75 \%$ of $\mathrm{C}$ and $13.5 \%$ of $\mathrm{G}$. According to data from previous studies on other primate species, genetic diversity in $R$. brelichi is lower than that of Macaca sylvanus, M. fuscata and other species in Rhinopithecus (Table 2) [18,19]. Although a variable site in $R$. brelichi might be found if the whole mitochondrial genome was sequenced, our result suggested that the intra-species diversity of $R$. brelichi is very low. The genetic diversity of $R$. roxellana and $R$. bieti, as revealed by analysis of the same mtDNA segment, are relatively higher than that of $R$. brelichi (Table 2). $R$. roxellana is more broadly distributed than any other snub-nosed species in China, and there are fifteen remaining populations of $R$. bieti in the area of northwest Yunnan Province and southeast Tibet. Different populations may have preserved the intra-species diversity of $R$. roxellana and $R$. bieti. However, there is only one extant population of $R$. brelichi, which might explain the extreme low diversity in this species.

Maintenance of genetic diversity is a major focus in conservation for a number of reasons. First, environmental change is a continuous process and genetic diversity is required for populations to evolve for adaptation to such change. Second, loss of genetic diversity is often associated with inbreeding and reduction in reproductive fitness. Low genetic diversity typically leads to increased levels of inbreeding, which can reduce the fitness of individuals. Consequently, IUCN recognizes the need to conserve genetic diversity as one of three global conservation priorities [20]. Compared with other primate species, intra-species genetic diversity of $R$. brelichi is very low, and thus immediate conservation management for this species is imperative. More attention should be given to $R$. brelichi because of the single haplotype and the very small population size about 750 individuals living in a small region in the Mt. Fanjing area. However, many challenging questions should be investigated before we can fully understand the ecology of $R$. brelichi. Genetic diversity is influenced by many factors and therefore varies considerably among species and populations. Moreover, estimates of genetic diversity solely based on a single marker can only provide preliminary data. Further studies should use long mitochondrial genome segments and nuclear molecular markers. Finally, as low

Table 2 Comparison of genetic diversity between the Guizhou snub-nosed monkey (Rhinopithecus brelichi) and other primate species (based on mtDNA control region data)

\begin{tabular}{lcccc}
\hline \multicolumn{1}{c}{ Species } & Sample size & Length $(\mathrm{bp})$ & Haplotype number & Haplotype diversities $(h)$ \\
\hline R. brelichi & 128 & 400 & 1 & 0 \\
R. roxellana & 60 & 379 & 12 & 0 \\
R. bieti & 157 & 401 & 30 & 0.033 \\
Macaca sylvanus & 280 & 468 & 24 & 0.034 \\
M. fuscata & 136 & 394 & 9 & 0.026 \\
\hline
\end{tabular}


genetic diversity might result in low immunity, we suggest that $e x$-situ conservation methods should be considered for part of the $R$. brelichi wild population to avoid potential risks of disease.

We thank the Administrative Bureau of Fanjing Mountain National Nature Reserve for its support, and Yang $X G$, Yang $S J$ and Dong $X H$ for their field assistance. This work was supported by the Fundamental Research Funds for the Central Universities (YX2011-33), the National Natural Sciences Foundation of China (30900142 and 30870375), the Project of Public Benefit (201104073), and the National Basic Research Program of China (2007CB411600).

1 Thomas G, Ngwe L, Saw S, et al. A new species of snub-nosed monkey, genus Rhinopithecus Milne-Edwards, 1872 (Primates, Colobinae), from Northern Kachin State Northeastern Myanmar. Am J Primatol, 2010, 72: 1-12

2 Jablonski N G. The evolution of the doucs and snub-nosed monkeys and the question of the phyletic unity of the odd-nosed colobines. In: Jablonski N G, ed. The Natural History of the Doucs and Snub-Nosed Monkeys. Singapore: World Scientific Publishing, 1998. 13-52

3 Jablonski N G. The response of catarrhine primates to Pleistocene environmental fluctuations in Asia. Primates, 1998, 39: 29-37

4 Quan G Q, Xie J Y. Research on the Golden Monkey (in Chinese). Beijing: Science and Education Publishing House, 2002

5 Long Y C, Kirkpatrick C, Zhong T, et al. Report on the distribution, population, and ecology of the Yunnan snub-nosed monkey. Primates, 1994, 35: 241-250

6 Long Y C, Kirkpatrick C, Zhong T, et al. Status and conservation strategy of the Yunnan snub-nosed monkey. Chin Biodiv, 1996, 4: $145-152$

7 Ren R M, Su Y J, Yan K H, et al. Preliminary survey of the social organization of Rhinopithecus [Rhinopithecus] roxellana in Shennongjia National Nature Reserve, Hubei, China. In: Jablonski N G, ed. The Natural History of the Doucs and Snub-Nosed Monkeys.
Singapore: World Scientific Publishing, 1998. 269-277

8 Li B G, Pan R L, Oxnard C E. Extinction of snub-nosed monkeys in China during the past 400 years. Int J Primatol, 2002, 23: 1227-1244

9 Xiang Z F, Nie S G, Chang Z F, et al. Current status and conservation of the gray snub-nosed monkey Rhinopithecus brelichi (Colobinae) in Guizhou, China. Biol Conserv, 2009, 12: 469-476

10 IUCN. IUCN Red List of Threatened Species. IUCN, Gland, Switzerland and Cambridge, UK, 2007. Retrieved from http: //www.iucnr edlist.org (Accessed February 20, 2008)

11 Moritz C. Applications of mitochondrial DNA analysis in conservation: A critical review. Mol Ecol, 1994, 3: 401-411

12 Nie S G, Xiang Z F, Li M. Preliminary reports on diet and social structure of gray snub-nosed monkeys (Rhinopithecus brelichi) at Yangaoping, Guizhou (in Chinese). Acta Theriol Sin, 2009, 29: 326331

13 Hayaishi S, Kawamoto Y. Low genetic diversity and biased distribution of mitochondrial DNA haplotypes in the Japanese macaque (Macaca fuscata yakui) on Yakushima Island. Primates, 2006, 47: $158-164$

14 Thompson J D, Gibson T J, Plewniak F, et al. The clustal_X Windows interface: Flexible strategies for multiple sequence alignment aided by quality analysis tools. Nucleic Acids Res, 1997, 25: 48764882

15 Kumar S, Tamura K, Jakobsen I B, et al. MEGA2: Molecular evolutionary genetics analysis software. Bioinformatics, 2001, 17: 1244-1245

16 Nei M. Molecular Evolutionary Genetics. New York: Columbia University Press, 1986

17 Rozas J, Rozas R. DNAsp version 3: An integrated program for molecular population genetics and molecular evolution analysis. Bioinformatics, 1999, 15: 174-175

18 Marmi J, Bertranpetit J, Terradas J, et al. Radiation and phylogeography in the Japanese macaque, Macaca fuscata. Mol Phylogenet Evol, 2004, 30: 676-685

19 Li Z X, Lin Z Y. Classification and distribution of living Primates in Yunnan, China (in Chinese). Zool Res, 1983, 4: 111-120

20 McNeely J A, Miller K R, Reid W V, et al. Conserving the World's Biological Diversity. Washington D C: IUCN, WRI, CI, WWF and World Bank, 1990

Open Access This article is distributed under the terms of the Creative Commons Attribution License which permits any use, distribution, and reproduction in any medium, provided the original author(s) and source are credited. 